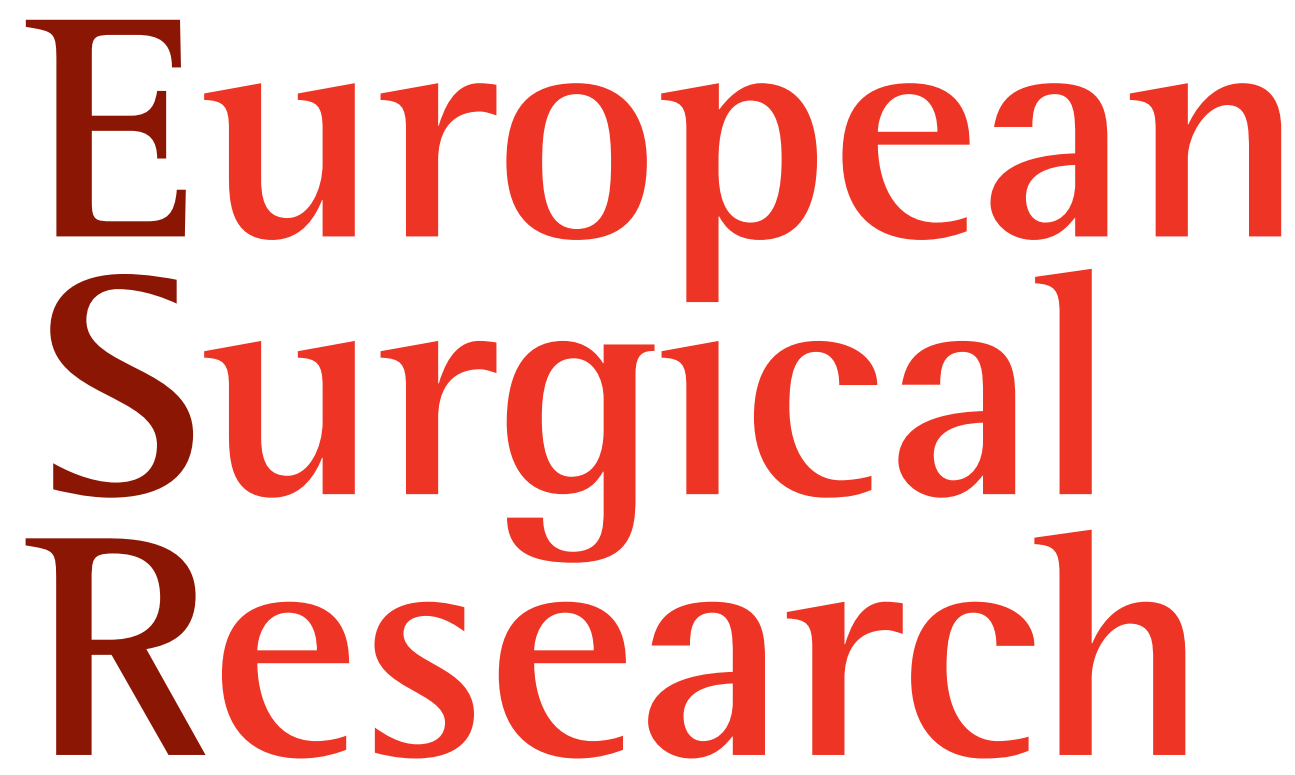

Clinical and Experimental Surgery

\title{
The 49th Congress of the European Society for Surgical Research
}

May 21-24, 2014, Budapest, Hungary

Congress Organizing Committee Attila Szijártó, Budapest

Péter Ónody, Budapest

Prof. Dr. György Wéber, Budapest 


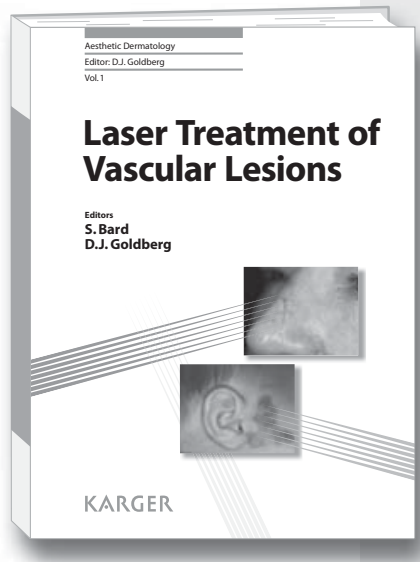

Laser Treatment of Vascular Lesions Editors: Bard S.; Goldberg D.J. (New York, N.Y.) VIII + 148 p., 46 fig. in color, 8 tab., 2014 CHF 112.- / EUR 93.- / USD 132.00 (hard cover) CHF 134.- / EUR 112.- / USD 158.00 (online) Online version for institutional purchase Prices subject to change

EUR price for Germany, USD price for USA and Latin America only

ISBN 978-3-318-02312-1 (hard cover) e-ISBN 978-3-318-02313-8

Aesthetic Dermatology, Vol. 1 Editor: Goldberg D.J. (New York, N.Y.)

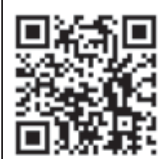

Dear Librarian

I have reviewed this publication and would like to recommend it for our library. Recommended by:

\section{Department:}

Date:

Signature:

Orders may be placed with any bookshop, subscription agency, directly with the publisher or through a Karger distributor.
Today, nearly 60 years after the invention of the first medical laser, multiple laser and light systems exist and are applied in various medical specialties such as dermatology, ophthalmology, and urology.

This volume - the first in the series Aesthetic Dermatology - focuses on the laser treatment of cutaneous lesions with a vascular target. Each chapter describes a particular laser or light modality and its specific application to a variety of both vascular and nonvascular lesions. Renowned specialists in laser medicine have contributed their expertise, incorporating current evidence-based literature and their own personal treatment recommendations, as well as pearls and perils.

The purpose of this book is to explore the options and parameters available to treat cutaneous lesions traditionally responsive to vascular laser therapy and to expand the application to further lesion treatments. Readers who wish to broaden their knowledge and further hone their skills in treating cutaneous vascular lesions with lasers will find this publication a valuable and comprehensive review.

\section{Contents}

- Foreword: Goldberg, D.J.

- Preface: Bard, s.

- Laser History, Physics, and Safety: Bard, s.

- Argon, Krypton, and Copper Lasers: Styperek, A.R.

- Pulsed Dye Laser: Waibel, J.S.

-Potassium-Titanyl-Phosphate (KTP) Laser: Green, J.B.; Serowka, K.; Saedi, N.; Kaufman, J.

- Alexandrite and Diode Lasers: Nouri, K.; Savas, J.A.; Ledon, J.; Franca, K.; Chacon, A.; Nouri, K.

- Nd:YAG Laser: Kaufman, J.

-Intense Pulsed Light: Chen, A.F.; Weiss, E.

- Complications of Vascular Laser Treatment: Grunebaum, L.D.; Bartlett, K.

\section{Author Index}

Subject Index 


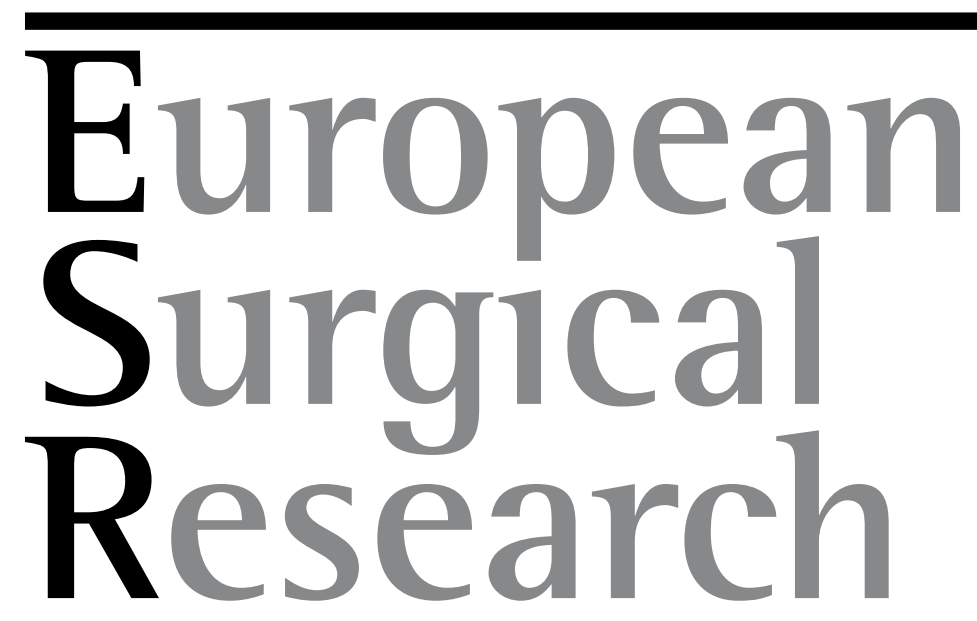

\section{Clinical and Experimental Surgery}

Founded 1969

Editors: W. Brendel (1975-1989†) and K. Messmer (1975-2005); O. Kempski (2005-2011)

\section{Editor-in-Chief}

B. Vollmar, Rostock

\section{Associate Editors}

M. Boros, Szeged

M. Büchler, Heidelberg

W.P. Ceelen, Ghent

M.D. Menger, Homburg/Saar

H. Thorlacius, Malmö/Lund

\section{Editorial Board}

I. Alwayn, Halifax

D.K. Bartsch, Marburg

C. Bassi, Verona

W.O. Bechstein, Frankfurt am Main

J.A. Bradley, Cambridge

M. Cikirikcioglu, Geneva

P.-A. Clavien, Zurich

R.W.F. de Bruin, Rotterdam

F.J.M.F. Dor, Rotterdam

C. Eipel, Rostock
S. Fichtner-Feigl, Regensburg

H. Friess, Munich

G. Galata, London

D.J. Gouma, Hilversum

J.K. Habermann, Lübeck

M. Heberer, Basel

T. Hubert, Lille

W.R. Jarnagin, New York, NY

J.C. Kalff, Bonn

M.W. Laschke, Homburg/Saar

H.-A. Lehr, Lausanne

C.M. Malata, Cambridge

T. Minor, Bonn

M. Morino, Torino

J. Pirenne, Leuven

A. Schachtrupp, Melsungen

R. Schramm, Munich

L. Steinstraesser, Bochum

A. Szijártó, Budapest

R.H. Tolba, Aachen

T.M. van Gulik, Amsterdam

M.A. Venermo, Helsinki

D.C. Winter, Dublin

Y. Yamamoto, Akita 


\section{Aims and Scope}

The prime mission of European Surgical Research is to publish high-quality original manuscripts of basic and translational research and review articles concerned with laboratory and clinical investigations which are relevant to surgical practice and of general interest to a broad range of academic surgeons and surgical researchers. Manuscripts dealing with research relevance to human surgical diseases are given high priority along with those which explore the pathogenesis, etiology, and mechanisms of disease processes. European Surgical Research seeks to preferentially publish research articles that in tegrate molecular biological methods, along with functional studies, into the analysis of biological questions and that advance basic and translational knowledge of surgical pathophysiology. European Surgical Research will provide an international platform for basic and translational research and clinical investigations impacting directly on surgical care and management. European Surgical Research also features special articles relating to educational, research, or social issues of interest to the academic surgical community.

\section{Submission}

Only original papers written in English are considered and should be submitted online:

\section{www.karger.com/esr}

All manuscripts must be accompanied by a cover letter and copyright signed by all authors. Assurance should be given in the cover letter that the manuscript is not under simultaneous consideration by any other publication.

Authors may suggest up to five referees who have expert knowledge on the subject. Suggested referees should not be from the same institution, not have published with the authors during the last 5 years, and should not be prejudiced.

Manuscripts may be submitted to the following sections: (1) Original Papers on basic, translational and clinical science

(2) Technical Notes

(3) Reviews

Original Papers: These manuscripts should represent original research in basic, translational, or clinical science. Consideration for publication is based on originality, novelty, scientific soundness, and appropriate analysis. European Surgical Research encourages the submission of relevant and well-conducted work in basic, experimental, and clinical science. Manuscripts should be prepared according to the guidelines for original papers.

Technical Notes: These manuscripts present a new meth od, experimental model, test procedure, tool, or algorithm that is relevant for surgical research and significantly advances current available knowledge.

Reviews in which a specific field is reviewed through an exhaustive literature survey. An Abstract is required and should be divided into Background, Summary and Key Messages. Review Articles should consist of a maximum of 4,000 words. European Surgical Research aims to publish expert basic and translational reviews of selected up-to-date topics in experimental surgery. On occasion the Editor-in-Chief will invite additional clinical or basic science reviews on a specific topic, which are usually presented pair-wise. Exceptions include formal true Systematic Reviews with Meta-Analyses which are well performed, and which are considered Original Papers.
Should you experience any problems with your submission, please contact: esr@karger.ch

Editorial Office 'European Surgical Research'

S. Karger AG

Angela Lorenz

PO Box

$\mathrm{CH}-4009$ Basel (Switzerland)

Tel. +41613061358

$\mathrm{Fax}+41613061434$

\section{Conditions}

All manuscripts are subject to editorial review. Manuscripts are received with the explicit understanding that they are not under simultaneous consideration by any other publication. Submission of an article for publication implies transfer of the copyright from the author to the publisher upon acceptance. Accepted papers become the permanent property of European Surgical Research and may not be reproduced by any means, in whole or in part, without the written consent of the publisher. It is the author's responsibility to obtain permission to reproduce illustrations, tables, etc. from other publications

\section{Disclosure Statement}

Authors are required to disclose any sponsorship or funding arrangements relating to their research and all authors should disclose any possible conflicts of interest. Disclosure statements will be published at the end of the text of the article.

\section{Plagiarism Policy}

Whether intentional or not, plagiarism is a serious violation. We define plagiarism as a case in which a paper reproduces another work with at least $25 \%$ similarity and without citation.

If evidence of plagiarism is found before/after acceptance or after publication of the paper, the author will be offered a chance for rebuttal. If the arguments are not found to be satisfactory, the manuscript will be retracted and the author sanctioned from publishing papers for a period to be determined by the responsible Editor.

\section{Ethics}

Published research must comply with the guidelines for human studies and animal welfare regulations. Authors should state that subjects have given their informed consent and that the study protocol has been approved by the institute's committee on human research. Further, they should also state that animal experiments conform to in stitutional standards. Authors are required to declare the approval codes obtained from the corresponding ethical committee on human and/or animal research.

\section{Arrangement}

The manuscript should conform to the following order: title page, abstract and key words, body, acknowledgments, references, figure legends, tables and figures. Manuscripts should be written in high-quality English suitable for effective communication to a professional medical audience. Authors who are not native speakers of English sometimes receive negative comments from referees or editors about the English-language usage in their manuscripts, and these problems can contribute to the decision to reject a paper. To help reduce the possibility of such problems, we strongly encourage such authors (i) to have their manuscript reviewed for clarity by a colleague whose native language is English and/or (ii) to use one of the many English language editing services that are available via the Web.

All pages, including the figure legends, should be numbered in sequence, and the first author's name should ap- pear at the upper right corner of each page. Papers not conforming to the journal style will be returned without review.

Title page: The first page of each paper should indicate a concise title of no more than 150 characters, all authors' names (first name and surname), authors' institutional affiliations, and a short title for use as running head.

Corresponding author: The exact postal address of author(s) to whom correspondence, proofs, and reprint requests should be sent, including the postal code, mus be given at the bottom of the title page. Please also supply phone and number and e-mail address.

Abstract of Reviews: Should be divided into the following subsections: Background, Summary and Key Messages. The Background should provide a brief clinical contex for the review and is followed by the Summary, which should include a concise description of the main topics covered in the text. The Key Messages encapsulate the main conclusions of the review.

Abstract of Original Papers and Technical Notes: Submit the abstract on a separate page. The abstract is structured into Background/Purpose, Methods, Results and Conclusions and should be less than 400 words in length.

Key words: Following the abstract, an alphabetical lis of five key words that reflect the content of the paper should be given.

Footnotes: Avoid footnotes.

Body of manuscript: The text should be organized into: Introduction, Materials and Methods, Results, Discussion, Acknowledgments, including grant numbers and sourc es of support, Disclosure/Duality of Interest (optional) and References. Abbreviations/acronyms are defined in both the abstract and body of the text as follows: vascular permeability factor (VPF); transforming growth factor$\beta$ (TGF- $\beta$ ). They should only be used in the abstract if they appear twice after first being mentioned and in the body of the text only if they appear three times after first being mentioned.

Tables and illustrations: Tables and illustrations (both numbered in sequential Arabic numerals) should be prepared as separate files. Tables require a brief and concise heading. Figures require a legend, prepared as a separate page, after references. Please use scale markers for electron micrographs, and indicate the type of stain used. For the reproduction of illustrations, only good drawings and original photographs can be accepted; negatives or photocopies cannot be used. Due to technical reasons, fig ures with a screen background should not be submitted. When possible, group several illustrations in one block for reproduction (max. size $180 \times 223 \mathrm{~mm}$ ) or provide crop marks. Electronically submitted b/w half-tone and color illustrations must have a final resolution of $300 \mathrm{dp}$ after scaling, line drawings one of 800-1,200 dpi.

\section{Color illustrations}

Online edition: Color illustrations are reproduced free of charge. In the print version, the illustrations are reproduced in black and white. Please avoid referring to the colors in the text and figure legends.

Print edition: Up to 6 color illustrations per page can be integrated within the text at CHF 800.- per page.

References: In the text identify references by Arabic numerals [in square brackets]. Material submitted for publication but not yet accepted should be noted as [unpublished data] and not be included in the reference list. The list of references should include only those publications which are cited in the text. Do not alphabetize; number references in the order in which

\section{KARGER}

E-Mail karger@karger.com www.karger.com
(C) 2014 S. Karger AG, Basel 
they are first mentioned in the text. The surnames of the authors followed by initials should be given. There should be no punctuation other than a comma to separate the authors. Preferably, please cite all authors. Abbreviate journal names according to the Index Medicus system. Also see International Committee of Medical Journal Editors: Uniform requirements for manuscripts submitted to biomedical journals (www.icmje.org).

Examples

(a) Papers published in periodicals: Chatel J-M, Bernard $\mathrm{H}$, Orson FM: Isolation and characterization of two complete Ara h 2 isoforms cDNA. Int Arch Allergy Immunol 2003;131:14-18.

(b) Papers published only with DOI numbers:

Theoharides TC, Boucher W, Spear K: Serum interleukin-6 reflects disease severity and osteoporosis in mastocytosis patients. Int Arch Allergy Immunol DOI: $10.1159 / 000063858$

(c) Monographs: Matthews DE, Fare-well VT: Using and Understanding Medical Statistics, ed 3, revised. Basel, Karger, 1996.

(d) Edited books: DuBois RN: Cyclooxygenase-2 and colorectal cancer; in Dannenberg AJ, Dubois RN (eds) COX-2. Prog Exp Tum Res. Basel, Karger, 2003, vol 37, pp 124-137.

Reference Management Software: Use of EndNote is recommended for easy management and formatting of citations and reference lists.

\section{Digital Object Identifier (DOI)}

S. Karger Publishers supports DOIs as unique identifiers for articles. A DOI number will be printed on the title page of each article. DOIs can be useful in the future for identifying and citing articles published online without volume or issue information. More information can be found at www.doi.org.

\section{Supplementary Materia}

Supplementary material is restricted to additional data that are not necessary for the scientific integrity and conclusions of the paper. Please note that all supplementary files will undergo editorial review and should be submitted together with the original manuscript. The Editors reserve the right to limit the scope and length of the supplementary material. Supplementary material must meet production quality standards for Web publication with out the need for any modification or editing. In general, supplementary files should not exceed $10 \mathrm{Mb}$ in size. All figures and tables should have titles and legends and all files should be supplied separately and named clearly. Acceptable files and formats are: Word or PDF files, Excel spreadsheets (only if the data cannot be converted properly to a PDF file), and video files (.mov, .avi, .mpeg).

\section{Author's Choice ${ }^{\mathrm{TM}}$}

Karger's Author's Choice ${ }^{\mathrm{TM}}$ service broadens the reach of your article and gives all users worldwide free and full access for reading, downloading and printing at www. karger.com. The option is available for a one-time fee of CHF 3,000.-, which is a permissible cost in grant allocation. More information can be found at www.karger. com/authors_choice.

\section{NIH-Funded Research}

The U.S. National Institutes of Health (NIH) mandates under the NIH Public Access Policy that final, peer-reviewed manuscripts appear in its digital database within 12 months of the official publication date. As a service to authors, Karger submits your manuscript on your behalf to PubMed Central (PMC) immediately upon publication. It usually receives a PMCID within approximately a month and will appear in PMC after 12 months. For those selecting our premium Author's Choice ${ }^{\mathrm{TM}}$ service, the usual embargo will be overridden, accelerating the accessibility of your work.

\section{Self-Archiving}

Karger permits authors to archive their pre-prints (i.e. pre-refereeing) or post-prints (i.e. final draft post-refereeing) on their personal or institution's servers, provided the following conditions are met: Articles may not be used for commercial purposes, must be linked to the publisher's version, and must acknowledge the publisher's copyright. Authors selecting Karger's Author's Choice ${ }^{\mathrm{TM}}$ feature, however, are also permitted to archive the final, published version of their article, which includes copyediting and design improvements as well as citation links.

\section{Page Charges}

A charge of CHF 125.- per page will be levied for the first 4 printed pages of an article. Any additional page will be charged to the author at CHF 325.-. The allotted size of a paper is equal to approx. 12 manuscript pages (including tables, illustrations and references).

\section{Proofs}

Unless indicated otherwise, proofs are sent to the corresponding author and should be returned with the least possible delay. Alterations other than the correction of printer's errors are charged to the author.

\section{Reprints}

Order forms and a price list are sent with the proofs. Orders submitted after the issue is printed are subject to considerably higher prices.

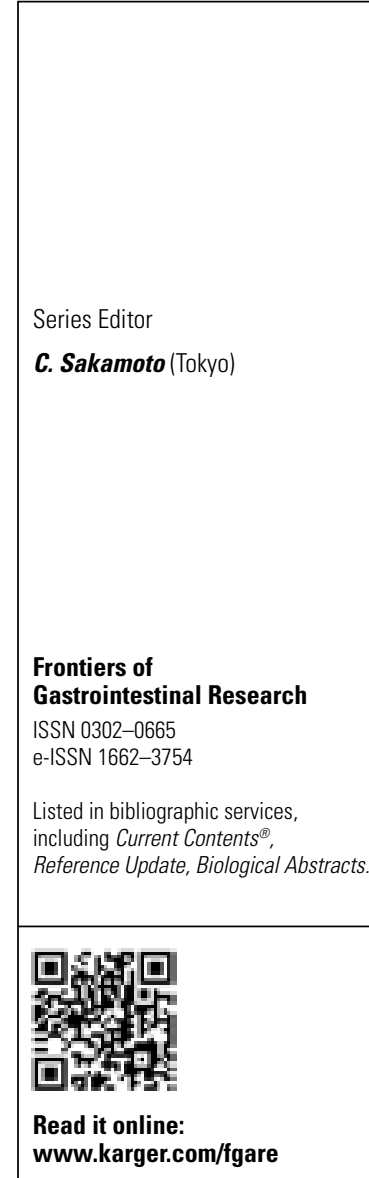

\section{Frontiers of} Gastrointestinal Research

\section{A guide to leading investigations in the field of gastroenterology}

This series is designed for both the physician active in the clinical practice of gastroenterology and the gastroenterologist or student engaged in research. Each volume offers a ready reference guide to current progress and a review of past achievement in a particular area of gastrointestinal study. The series covers pathological, pharmacological, diagnostic and therapeutic considerations relating to the digestive system, as well as the latest techniques and instrumentation used in the management of gastrointestinal disorders.

\author{
Vol. 33: Functional and GI \\ Motility Disorders \\ Editors: Quigley, E.M.M. (Houston, \\ Tex.); Hongo, M. (Kurokawa); Fukudo, \\ S. (Sendai) \\ VIII + 176 p., 17 fig., 6 in color, 10 tab. \\ hard cover, 2014 \\ CHF 178.- / EUR 148.- / USD 209.00 \\ ISBN 978-3-318-02578-1
}

\section{Vol. 32: Proton Pump Inhibitors A Balanced View \\ Editors: Chiba, T. (Kyoto); Malfertheiner, P. (Magdeburg); Satoh, H. (Kyoto) \\ $\mathrm{VIII}+120$ p., 28 fig., 2 in color 17 tab., hard cover, 2013 CHF 178.- / EUR 148.- / USD 209.00 ISBN 978-3-318-02415-9}

\section{Vol. 31: Fluorescent Imaging \\ Treatment of Hepatobiliary and Pancreatic Diseases Editors: Kokudo, N. Ishizawa, T. (Tokyo) $\mathrm{VIIII}+124$ p. 34 fig. 23 in color 8 tab., hard cover, 2013 CHF 178.- / EUR 148.- / USD 209.00} ISBN 978-3-318-02292-6

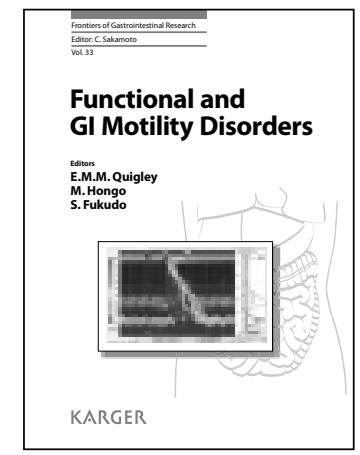

(a)

Vol. 30: Cell/Tissue Injury and Cytoprotection/0rganoprotection in the Gastrointestinal Tract

Mechanisms, Prevention and Treatment

Editors: Filaretova, L.P. (St. Petersburg); Takeuchi, K. (Kyoto) VIII + 250 p., 49 fig., 10 tab. hard cover, 2012 CHF 182.- / EUR 152.- / USD 214.00 ISBN 978-3-318-02183-7 
ISSN Print Edition: 0014-312X

ISSN Online Edition: 1421-9921

Journal Homepage: www.karger.com/esr

Publication Data: 'European Surgical Research' is published 8 times a year. Volumes 52 and 53, each with 4 issues, appear in 2014.

Copyright: (c) 2013 S. Karger AG, Basel (Switzerland). All rights reserved. No part of this publication may be translated into other languages, reproduced or utilized in any form or by any means, electronic or mechanical including photocopying, recording, microcopying, or by any information storage and retrieval system, without permission in writing from the publisher or, in the case of photocopying, direct payment of a specified fee to the Copyright Clearance Center.

Disclaimer: The statements, opinions and data contained in this publication are solely those of the individual authors and contributors and not of the publisher and the editor(s). The appearance of advertisements in the journal is not a warranty, endorsement, or approval of the products or services advertised or of their effectiveness, quality or safety. The publisher and the editor(s) disclaim responsibility for any injury to persons or property resulting from any ideas, methods, instructions or products referred to in the content or advertisements.
Subscription Rates: Subscriptions run for a full calendar year. Prices are given per year. Personal subscription:

Print or Online

CHF 806.-

EUR 661--

USD 806.00

Print+Online combined

EUR 739.

USD 902.00

postage and handling (added to print and print+online)

CHF 59.20 Europe, CHF 86.40 Overseas

EUR 48.00

USD 78.40

Institutional subscription:

Print or Online

Print+Online combined

CHF 2686.-

EUR 2202.-

CHF 2954.-

postage and handling (added to print and print+online)

CHF 74.- Europe, CHF 108.- Overseas

EUR 60.-

USD 98.00
Back Volumes and Single Issues: Information on availability and prices of single print issues and print or electronic back volumes can be obtained from Customer Service at service@karger.om.

Bibliographic Indices: This journal is regularly listed in bibliographic services, including Current Contents ${ }^{\circledR}$ and PubMed/MEDLINE.

Photocopying: This journal has been registered with the Copyright Clearance Center (CCC), as indicated by the code appearing on the first page of each article. For readers in the US, this code signals consent for copying of articles for personal or internal use, or for the personal or internal use of specific clients, provided that the stated fee is paid per copy directly to

Copyright Clearance Center Inc.

222 Rosewood Drive

Danvers, MA 01923 (USA)

A copy of the first page of the article must accompany payment. Consent does not extend to copying for general distribution, for promotion, for creating new works, or for resale. In these cases, specific written permission must be obtained from the copyright owner,

S. Karger AG, P.O. Box

CH-4009 Basel (Switzerland).

\section{Subscription Orders:}

Orders can be placed at agencies,

bookstores, directly with the Publisher

\section{S. Karger AG}

Medical and Scientific Publishers

Allschwilerstrasse 10

CH-4009 Base

Switzerland

t: +41613061111

f: +41613061234

e: karger@karger.com

w: www.karger.com

(for courier services only:

Allschwilerstrasse 10

CH-4055 Basel) or further Karger offices

or representatives:

\section{Germany}

S. Karger GmbH

Postfach

79095 Freiburg

Deutschland

(Hausadresse: Wilhelmstrasse 20A

79098 Freiburg)

t: +49761452070

f: +497614520714

e: information@karger.de

w: www.karger.de

Japan

Karger Japan, Inc.

Shiba Daimon Asahi Bldg. 2F

1-2-23 Shiba Daimon

Minato-ku

Tokyo 105-0012

Japan

t: +81364356242

f: +81364356244

e: publisher@karger.jp

w: www.karger.jp
USA

S. Karger Publishers, Inc.

26 West Avon Road

P.O. Box 529

Unionville, CT 06085

USA

Toll free: +18008285479

t: +18606757834

f: +18606757302

e: karger@snet.net

France

Enter \& Read

Albertine Luginbuh

23 , rue du Départ, boite 37

75014 Paris

France

t: $+33(0) 681047685$

e: albertineluginbuhl@orange.fr

South East Asia, China and Taiwan

Karger Regional Office (Malaysia)

CEO Suite Kuala Lumpur

Quill 7, 27th Floor

Jalan Stesen Sentral 5

KL Sentral

Kuala Lumpur 50470

Malaysia

t: +60327766803

f: $\quad+60327766999$

e: service@karger.cn

\section{Karger China}

West/5F, China Life Towe

No.16, Chao Wai Street

Chaoyang District

Beijing 100020

China

t: +861058771408

f: +861058771120

e: service@karger.cn; r.chew@karger.cn

w: www.karger.cn

India, Bangladesh, Sri Lanka

Karger India

Plot No. 17, Yusuf Sarai Market

B.L. Glass Building, 2nd Floor

Sri Aurobindo Marg

New Delhi 110016

India

t: +911146029633

f: +911146029634

c: +919891052128

e: r.kumar@kargerindia.com

w: www.karger.com

Change of Address:

Both old and new address should be sent

to the subscription source.

\section{KARGER}

E-Mail karger@karger.com www.karger.com
(C) 2014 S. Karger AG, Basel

The Guidelines for Authors are available at: www.karger.com/esr_Guidelines 


\section{Contents}

See the journal website for contents

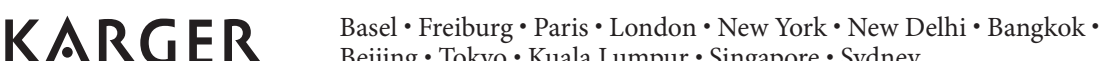
Beijing $\cdot$ Tokyo $\cdot$ Kuala Lumpur $\cdot$ Singapore $\cdot$ Sydney 


\section{Be at the forefront of the latest developments in experimental surgery}

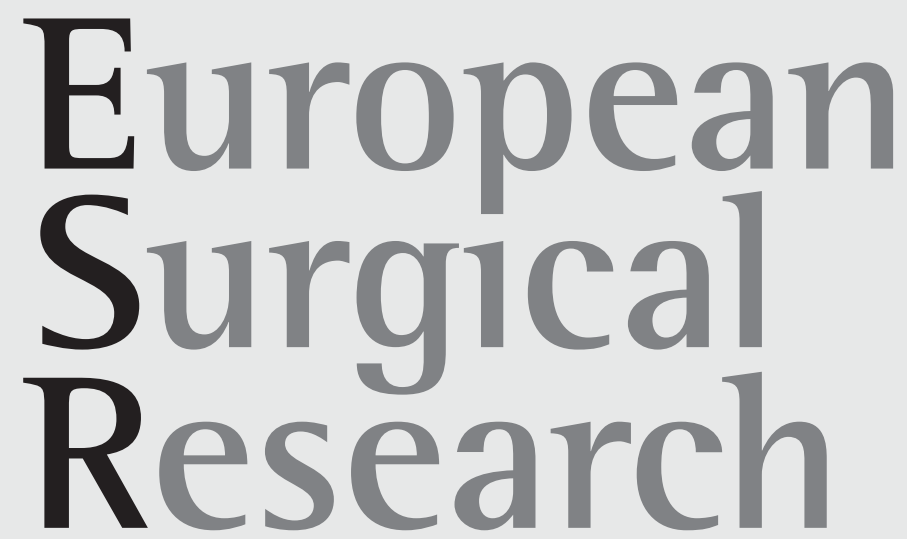

Clinical and Experimental Surgery

Editor-in-Chief

B. Vollmar, Rostock

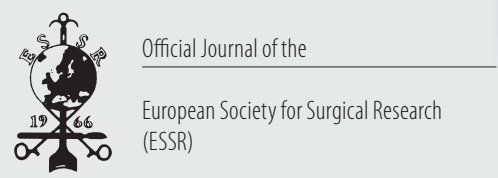
(ESSR)

\section{European Surgical Research}

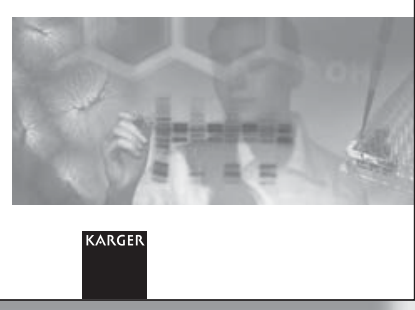

European Society for Surgical Research

\section{More information at}

\section{www.karger.com/esr}

- Pay-per-View and Subscriber Access to Full Text

- Full Table of Contents

- Full Editorial Board

- Free Abstracts and Selected Articles

- Online Sample Issue

- Submission/Guidelines for Authors

- Subscription Details

- Free Alert Service

- Online Library Recommendation

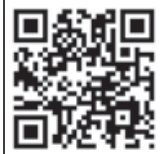

European Surgical Research

2014: Volumes 52, 53

4 issues per volume

Language: English

ISSN 0014-312X

ISSN online 1421-9921

\section{Selected contributions}

- Local Ischaemia Does Not Influence Anastomotic Healing: An Experimental Study: Daams, F.; Monkhorst, K.; van den Broek, J.; Slieker, J.C.; Jeekel, J.; Lange, J.F. (Rotterdam)

- Tissue-Engineered Devices in Cardiovascular Surgery: Klopsch, c.; Steinhoff, G. (Rostock)

- In vivo Evaluation of the Chitosan-Based Haemostatic Agent Omni-stat ${ }^{\oplus}$ in Porcine Liver Resection and in Liver Injury: Jegatheeswaran, S. (Manchester);

Bhanot, U. (New York, N.Y.); Siriwardena, A.K. (Manchester)

- An Ergonomic Study of Single-Port versus Multi-Port Laparoscopic Mesh Insertion for Ventral Hernia Repair: López-Cano, M.; Pereira, J.A.; Mojal, S. (Barcelona); Lozoya, R. (Sagunto); Quiles, M.T.; Arbós, M.A.; Armengol-Carrasco, M. (Barcelona)

- Does Nuclear Factor-Kappa B in Peripheral Mononuclear Cells Have a Prognostic Role during Acute Necrotizing Pancreatitis in Rats?: Alhan, E.; Türkyılmaz, S.

(Trabzon); Erçin, C. (Kocaeli); Kural, B.V. (Trabzon); Flinte, D. (Kocaeli)

- Early Enteral Nutrition Reduces the Rate of Life-Threatening Complications after Thoracic Esophagectomy in Patients with Esophageal Cancer: Fujita, T.; Daiko, H.; Nishimura, M. (Kashiwa)

- Apoptosis-Modulating Drugs for Improved Cancer Therapy: ocker, M. (Marburg);

Höpfner, M. (Berlin)

- Postoperative Adhesion Prevention with a New Barrier: An Experimental Study: Ditzel, M.; Deerenberg, E.B. (Rotterdam); Komen, N. (Edegem); Mulder, I.M.; Jeekel, H.; Lange, J.F. (Rotterdam)
European Surgical Research features original clinical and experimental papers, condensed reviews of new knowledge relevant to surgical research, and short technical notes serving the information needs of investigators in various fields of operative medicine. Coverage includes surgery, surgical pathophysiology, drug usage, and new surgical techniques. Special consideration is given to information on the use of animal models, physiological and biological methods as well as biophysical measuring and recording systems. The journal is of particular value for workers interested in pathophysiologic concepts, new techniques and in how these can be introduced into clinical work or applied when critical decisions are made concerning the use of new procedures or drugs. 


\section{European \\ Surgical \\ Research}

Abstracts

93 The 49th Congress of the European Society for Surgical Research May 21-24, 2014, Budapest, Hungary

Congress Organizing Committee: Szijártó, A.; Ónody, P.; Wéber, G. (Budapest)

251 ESSR News

after 252 Contents Vol. 52, 2014 